2019-08-28

\title{
What Happens in the Beginning, Matters in the End: Achieving Best Evidence with Child Suspects in the Police Station
}

\author{
von Berg, Piers
}

http://hdl.handle.net/10026.1/14768

\subsection{7/1473225419868840}

Youth Justice: an international journal

SAGE Publications

All content in PEARL is protected by copyright law. Author manuscripts are made available in accordance with publisher policies. Please cite only the published version using the details provided on the item record or document. In the absence of an open licence (e.g. Creative Commons), permissions for further reuse of content should be sought from the publisher or author. 


\title{
What Happens in the Beginning, Matters in the End: Achieving Best Evidence with Child Suspects in the Police Station
}

\begin{abstract}
During the last 30 years, the way in which children give evidence in the criminal justice system in England and Wales has been radically transformed. These reforms have, however, neglected child suspects in the police station. Recent piecemeal reforms to the statutory regime for children in police detention have overlooked a critical stage of the criminal justice process: the police interview. This article critically analyses the policy, practice and law surrounding police questioning of child suspects. It demonstrates that the absence of child-specific guidance when interviewing child suspects, is not only out of step with wider reforms, but carries real risks regarding the effective communication and participation of child suspects.
\end{abstract}

\section{Key Words: children, evidence, interviews, police, rights}

'Effective communication is the bedrock of the legal process... Check that all parties understand ... the meaning of the questions asked and answers given during the course of the proceedings, otherwise the process of law is at best seriously impeded. At worst, justice may be denied'.

\section{(Judicial College, Fairness in Courts and Tribunals 2012)}

\section{Introduction}

How evidence is obtained from children in the criminal justice system - as witnesses, complainants, suspects and defendants - has come under increasing attention and scrutiny over the last 30 years. Published in the wake of the Cleveland Inquiry, Dame Butler-Sloss' report recognised the questioning of children as a specialist skill requiring training, preparation and appropriate execution (Butler-Sloss 1988). Subsequently, the Achieving Best Evidence (ABE) guidance (Ministry of Justice, 2011) was designed to assist police officers in securing accurate and reliable testimony from child witnesses and victims. In court, child witnesses and victims may have the support and assistance of an intermediary and 'special measures' under the Youth Justice and Criminal Evidence Act 1999. In addition, special hearings are now required to agree the 'ground rules' of questioning and thereby transformed it. These changes have been largely confined to obtaining evidence from vulnerable witnesses and complainants, and only recently expanded incrementally to such defendants with the availability of live links and the recognition of the Advocacy Training Council's toolkits as 'best practice' (Criminal Practice Directions [2015] EWCA Crim 1567, 3D.7-8).

Although more can be done to improve compliance with the ABE guidance and the use of special measures (Charles, 2012), their mandated use is an important statement about the vulnerability of children and their continuing maturation. No equivalent safeguards and training such as the $\mathrm{ABE}$ guidance exist or apply for child suspects interviewed by the police. This failure is consistent with the wider picture of the treatment of child suspects in police custody where children are treated first and foremost as offenders and as mini-adults (Her Majesty's Inspectorate of Constabulary and Fire and Rescue Services (HMICFRS - formerly HMIC), 2015, 2019; Dehaghani, 2017). HMIC inspections have repeatedly criticised the failures to transfer to local authority accommodation after refusal of bail, inadequate provision of support by 
appropriate adults and unsatisfactory ways of assessing and recording risk to children (HMIC et al 2011; HMIC 2015, 2016; HMICFRS 2019). In addition, a high-profile campaign coordinated by Just for Kids Law and the Howard League for Penal Reform culminated in the landmark case $R(H C) v$. Secretary of State for the Home Department and the Commissioner of the Police of the Metropolis [2013] EWHC 982 (Admin), paved the way for significant statutory changes in order for 17-year olds to be treated as juveniles and not adults (see Author, 2013).

Such reforms are welcomed, but have overlooked a critical aspect of the process: the interrogation of child suspects. This is a significant oversight. At time of writing, over 60,000 children are arrested and taken to the police station each year, where the vast majority, if not all, will be interviewed (Ministry of Justice, 2017). The Youth Justice and Criminal Evidence Act 1999 recognises that children under the age of 18 are 'vulnerable', however, limited consideration has been given to extent to which this might influence the responses of child suspects in the police station. Yet, the interview is the first point at which a suspect might provide an exculpatory or inculpatory account on record from which many pivotal decisions may then flow such as the commencement of criminal proceedings.

This article represents the first attempt to consider whether the existing law, policy and practice regarding police interviewing of child suspects in England and Wales is fit for purpose. Whilst the available literature focuses on police interviews generally (see, for example, Griffiths and Milne, 2006; Soukara et al, 2007; Williamson, 2015; Walsh and Bull, 2010), few studies have considered the special position of child suspects (although note more broadly, Quinn and Jackson, 2007; Feld, 2006, 2014; Panzavolta et al, 2015). Recent domestic reviews of police custody and the youth justice system (Charlie Taylor Review, 2016) have also overlooked the interview process in their inquiries. This article seeks to address this gap. It begins by setting out the current approach to police interviewing of child suspects, drawing on responses to Freedom of Information requests. Secondly, the article compares and contrasts the current approach for questioning of child witnesses and defendants on one hand, and child suspects on the other. Ultimately, it is argued that the policy regarding child suspects has been left behind by reforms to the questioning of vulnerable witnesses and defendants. It considers the consequences of this for the fulfilment of obligations by the police under the Human Rights Act 1998 to ensure there is a fair process (Article 6). Irrespective of their status, approaches to all children should be directed to the same purpose - to secure accurate and reliable testimony. For the child suspect, effective participation in the criminal justice process, as required by Article 6 is premised on effective communication. As a result, it is argued, consideration must be given to developing assessment tools and training to assist any police officer interviewing a child suspect. This is a critical to upholding the right to a fair trial and safeguarding a child's welfare since what happens at the first point of contact matters for the fairness of the trial and the child's future wellbeing.

\section{Interviewing Child Suspects}

The modern evolution of police interviewing of suspects can be traced back to the introduction of the Police and Criminal Evidence Act 1984 and its accompanying Codes of Practice. The police interview is a central part of the larger investigative process. In law, the interview 'is the questioning of a person regarding their involvement or suspected involvement in a criminal offence or offences which ... must be carried out 
under caution' (Police and Criminal Evidence Act (PACE) 1984, Code C para 11.1A). Although national guidance stipulates that the purpose of the 'investigative interview' is to 'obtain a full and accurate account,' (College of Policing, 2013) securing a confession is still often seen by police officers as the primary purpose of the investigative interview and a mark of professional competence (Williamson, 2015). As Sanders et al note (2012: 848), 'Even when other ways of securing the evidence are available, interrogation often serves as a 'short cut' and produces information of other offences and other offenders.' From the perspective of the accused, the police interview represents the first opportunity to respond to allegations and provide their own account and is often a source of vital inculpatory or exculpatory evidence. The precise nature of the predicament that a child suspect finds themselves in is set out in the caution at the beginning of a police interview:

"You do not have to say anything. But it may harm your defence if you do not mention when questioned something which you later rely on in Court. Anything you do say may be given in evidence."

The situation is that first they are under suspicion. Secondly, they are to be questioned by a person gathering evidence as part of a criminal investigation against them. The information supplied during the police interview will determine many decisions regarding the child's continued involvement in the criminal justice process, including the decision to charge, caution, bail and remand. Moreover, what is or is not said in police interview may form a critical part of the prosecution's case.

Despite its significance of the interview, child suspects are often ill equipped to effectively engage in the process. It is arguably the point at which the vulnerability of a child in the criminal justice process is greatest (Panzavolta and de Vocht, 2015). Police officers hold the advantage, controlling the flow of information, having a more detailed understanding of the law, holding the power to make decisions about detention and charge and controlling how, when and where detainees can access support and basic amenities. Detention and questioning in the police station is an intimidating and daunting prospect for many suspects irrespective of age. There is an inevitable power imbalance that exists when suspects are deprived of their liberty and required to navigate the complexities of the criminal justice process. When the suspect in question is a 'juvenile' (defined as a person under the age of 18 by section 37.15 of the Police and Criminal Evidence Act (PACE) 1984), this vulnerability is far more pronounced.

The young age and on-going maturation and development of children are such that juveniles may find the environment of the police station that much more distressing and disorientating. The All-Party Parliamentary Group for Children received evidence 'which suggested that many children and young people who are arrested find the experience highly stressful and traumatic' (2013-2014: 13). These concerns are amplified in police custody where a child may be subject to a variety of intrusive procedures and arguably frightening experiences. For example, child suspects are increasingly strip-searched, detained in police cells and held in police detention overnight, rather than local authority accommodation (HMIC, 2015; Gander, 2014; Bowcott, 2015; Skinns, 2011; Jivanda, 2014). Many of these concerns were reiterated by the Charlie Taylor Review (2016), which recommended among other things that children should only be detained in police custody as a last resort. 
A child's competency or fitness to be interviewed involves understanding the purpose of the interview, the questions asked and the significance of the answers given (Code of Practice C). This is undermined by suggestibility (where an interviewee changes their mind as a result of pressure or suggestion) and compliance (where an interviewee goes along with the suggestions of others without agreeing to them). Children are particularly prone to suggestibility, and the younger the child, the more suggestible they are in police interrogations (Grisso et al, 2003). During an interview, a child suspect is required to make choices on when and how to exercise their rights and answer questions (Panzavolta et al, 2015). Children may be understandably tempted to acquiesce in order to leave the police station as soon as possible (Redlich and Goodman 2003). In the United States, this desire has yielded false confessions to even very serious offences (Feld, 2006, 2014; Scott-Hayward, 2007). Gudjonsson (1990) also found that individuals gave distorted or incomplete accounts and even false confessions when susceptible to pressure. Children are also hampered by a reduced ability to recall events. Blandón-Gitlin and Pezdek (2009) showed that children have difficulty remembering events that had not occurred repeatedly or within days as opposed to months before. Such difficulties depend on variations in age and maturation. Vizard argues that if a child meets its developmental milestones, one would hope to find a 'considerable degree of intellectual maturation' by age 14 (2006: 49). However, developmental delay can result from factors such as abusive parenting or socioeconomic deprivation, factors that are all too common with child suspects (Vizard 2006).

These concerns about a child's ability to provide a reliable and accurate account are heightened when one considers the complex welfare needs typically presented by children in the criminal justice system. These include: emotional and mental health concerns, low IQ, low literacy levels, special educational needs, communication difficulties, experience of abuse, trauma, loss or neglect, mental health, and substance misuse issues (Talbot, 2010; Bryan et al, 2007; Harrington and Bailey, 2005; Hughes et al, 2012, Law Commission, 2016, Grisso, 2004). Whilst studies tend to focus on children who are at the sharp end of the criminal justice system, such as those in youth custody (Goldson, 2006, Author, 2013), children who come to the attention of the police are deemed 'doubly vulnerable' or the 'most vulnerable of the vulnerable' because of the above factors (Jacobson and Talbot 2009; HMIC 2011; see also Vizard 2006 and Bateman, 2017). The Children Act 2004 imposes a responsibility on the police to exercise their duties with regard to the welfare of the child. Inspections of custody find police officers tend to see child suspects as offenders, rather than children, ultimately overlooking their welfare needs (HMIC, 2015: 18). These concerns have led some to call for an independent assessment of child defendants and specialist training for all who work with them (Vizard 2006; Michael Sieff Foundation 2002).

Current policy and practice have not been effective in identifying and assessing the abilities of suspects in interview. In 2004, Code of Practice C was amended to include Annex $G$ that set out factors that a custody officer should consider when assessing a detainee's fitness to be interviewed. Police surgeons had previously complained of a lack of guidance to conduct fitness to interview assessments and the consequent risk of miscarriages of justice (Protheroe and Roney 1996; Norfolk 1996; Gregory 2004). Officers are now directed to consider any physical or mental state that might affect a detainee's ability to understand the nature and purpose of the interview, to understand questions and make decisions about exercising their right to silence (Code 
C). In some forces, this takes the form of 16 different questions and nine observational cues (National Strategy for Police Information Systems) although this has been criticised as inadequate with detection rates of about $25 \%$ for intellectual disability (McKinnon et al, 2015). It is not uncommon for police officers to proceed against advice not to interview in serious cases (Ventress et al, 2016). The use of Annex G is also dependent on the ability of those present - whether police, legal representatives or appropriate adults - to identify the problems. In DPP $v R$ [2007] EWHC 1842 (Admin), the High Court overturned a conviction for sexual assault because it was based on admissions in interview by a child in the lower $0.1 \%$ of population on the full-scale Wechsler test. This only came to light because the child was assessed post-interview by a consultant psychologist. At interview, the Court found that 'no one had any idea how dangerous the information-gathering process was when dealing with a boy of this level of handicap and this level of suggestibility' [para 6]. This is representative of wider problems: custody nurses report that the criteria for assessment are unclear and training insufficient (Peel, 2016) and the Bradley Report (2009) called for greater access to information on an individual shared by various agencies. Therefore, despite the requirement for assessment, there are notable problems with the tools, guidance, level of training and access to information.

Without informed and appropriate assessments of an interviewee, there is very limited other guidance to assist police officers in securing reliable evidence from child suspects. The Notes of Guidance accompanying Code of Practice C state:

'Although juveniles ... are often capable of providing reliable evidence, they may, without knowing or wishing to do so, be particularly prone in certain circumstances to provide information that may be unreliable, misleading or self-incriminating. Special care should always be taken when questioning such a person, and the appropriate adult should be involved if there is any doubt about a person's age, mental state or capacity. Because of the risk of unreliable evidence it is also important to obtain corroboration of any facts admitted whenever possible.' (para 11C)

These Notes of Guidance, and the subsequently released the Home Office guidance (2014), fail to define 'certain circumstances' or 'special care', or indeed how it might be practiced, adding little to the guidance available in Code of Practice C. Moreover, neither PACE nor the accompanying Codes of Practice offer any further guidance regarding the manner of questioning, the organisation of the interview and any special features concerning child suspect interviews (O'Mahony et al, 2012). There are other safeguards under PACE which apply later in criminal proceedings that can exclude evidence obtained in oppressive circumstances or circumstances that render the evidence unfair (see below on sections 76 and 78). But these statutory provisions are not a positive duty to properly assess a child suspect and plan and conduct an interview accordingly. The glaring omission is that neither PACE 1984, Code C, nor the case law on interviewing of suspects consider or refer to what is now recognised as the best practice for questioning child witnesses and defendants such as the ABE Guidance or the Advocacy Training Council's toolkits (see below).

Another potential safeguard contained in PACE and Code of Practice $\mathrm{C}$ is the appropriate adult. An appropriate adult can be a parent/guardian, a social worker, or a volunteer appropriate adult (Code of Practice C: para 1.7). The appropriate adult must 
be present for a wide range of critical events in police custody including inter alia cautioning, charging, explanation of the allegations, and when certain samples are taken (see Crime and Disorder Act 1998; Code C; and, PACE 1984). Their role is to advise the person being interviewed, observe whether the interview is conducted fairly and properly, and, facilitate communication with the interviewee (Code C: para 11.7). In many ways, the appropriate adult represents the key safeguard for children in the police station and serves as a 'gateway to a young person's access to justice' (HC para 63). However, in practice, appropriate adults are often unable to perform this role effectively.

Appropriate adults are not trained in how the police should conduct interviews of suspects, nor are they trained in how children can give their best evidence (Pierpoint, 2000a; 2000b, 2011; Kemp and Hodgson, 2016). It is perhaps then unsurprising that appropriate adults are often unclear about their role and often unable to safeguard either the welfare of the child or their due process rights of the child (Sanders et al, 2014; HMIC, 2011, Pierpoint, 2006). In the vast majority of cases, it is a parent who acts as the appropriate adult, but parents may exhibit high levels of distress and hostility (Bucke and Brown, 1997). Parents often make little or no contribution, and often see their role as either assisting the police - by chastising the child or urging the child to tell the truth - or hindering the police - becoming openly hostile and encouraging the child to say little (Pierpoint, 2000a, 2011; Bucke and Brown, 1997). Whilst social workers might find it easier to adopt a more neutral or objective role, research suggests that they contribute less than parents do and tend to be 'passive observers' (Evans, 1993; Pierpoint, 2000b). Volunteer appropriate adults are more likely to stop interviews due to unfair questioning or a lack of understanding on the part of the suspect, but lack a knowledge of the child, their specific needs or vulnerabilities, and how best to engage them (Pierpoint, 2000a, 2011). Irrespective of who performs the role, a clear power differential remains between the appropriate adult and the police officer (Pierpoint, 2000a; 2000b; Kemp and Hodgson, 2015). In his recent review of the youth justice system, Charlie Taylor concluded that the role of the appropriate adult is 'ill understood and variably exercised,' with appropriate adults in need of greater training, development and support (2016: 20-21). Thus, the presence of an appropriate adult is not a sufficiently robust safeguard.

All suspects have the right to consult legal advice and the Code of Practice C Notes for Guidance (para 6D) permits that:

The solicitor may intervene in order to seek clarification, challenge an improper question to their client or the manner in which it is put, advise their client not to reply to particular questions, or if they wish to give their client further legal advice.

The value of this in ensuring effective communication is dependent on a number of factors. First, often a child and/or an appropriate adult consents to an interview without a solicitor present (Kemp et al, 2011; Taylor 2016; Pierpoint, 2011). PACE 1984 allows for situations when a detainee can be questioned without a solicitor present and although there are wide variations in the request rates for legal advice by children (Kemp et al 2011), suspects aged 10-13 are less likely to seek legal advice (Pleasence et al 2011). Charlie Taylor recommended that there should be a presumption that a solicitor attends and there is training provided to them on how to work with young 
clients. Strictly speaking, it is not the role or part of the training of a solicitor to help a child communicate effectively. Their primary duty is to protect the interests of their client, which may involve advising their client not to answer some or even all questions. Finally, whilst some solicitors may be quick to recognise and challenge unhelpful or oppressive lines of questioning, solicitors are not trained in the application of the techniques from the ABE Guidance or necessarily the Advocacy Training Council toolkit for questioning child defendants. Taken together, the possibility of the assistance of an Appropriate Adult and, potentially a legal representative, are not the appropriate means for improving communication.

\section{Questioning Child Suspects in Practice}

In February 2015 and February 2016, the authors sent Freedom of Information (FOI) Requests to all police forces in England as well as the Home Office, the Association of Chief Police Officers and the College of Policing. These FOI requests posed questions regarding local policies, practices, procedures, assessments and training, focusing specifically on interviews with child suspects. The study was not designed as an indepth analysis of policing practices across England and Wales. Rather, it was an exploratory process aimed at determining whether any national guidance had been developed regarding interviews with child suspects to complement the Achieving Best Evidence guidance for child victims or witnesses, or, indeed whether ABE was used for child suspects by default. If neither applied, the FOI requests sought to determine whether police forces were developing their own local guidance or capturing the need for a careful approach within staff training or through the purposeful allocation of highly trained officers to child suspect interviews. Essentially, the FOI requests were concerned with whether or not child suspects were treated in the same manner as adult suspects or whether recognition was given to their vulnerability in the same way as witnesses and victims. This approach was taken due to a lack of data on what guidance the police used beyond that found in Code $\mathrm{C}$ and the Authorised Professional Practice provided by the College of Policing.

The responses generated five key findings. First, none of the police forces had separate policies or guidance covering interviews with child suspects. Second, police forces tended to rely on PACE, predominantly Code $\mathrm{C}$, and refer to the assistance of the appropriate adult when dealing with child suspects. One force, Hampshire Constabulary, suggested that in order to maintain compliance with Code of Practice C of PACE, 'there is no real scope for additional interpretation or instruction'. Third, police forces often referred to the Authorised Professional Practice guidelines, but these do not offer specific guidance regarding interviews with child suspects. Fourth, none of the forces adopted the ABE Guidance when interviewing child suspects, although Greater Manchester Police said that 'the bulk of the knowledge of how to deal with child suspects is transferred over from child witness training.' This is a significant finding because previously it was suggested that officers would look to the ABE Guidance for assistance in interviewing vulnerable suspects because PACE Code C lacks it (O'Mahony et al 2012). Fifth, a small number of forces involved medical practitioners in an assessment of the child conduct their own checks prior to interview. ${ }^{1}$ It was not clear how these assessments were conducted, on what basis they were initiated or what factors were considered during the assessment. This is of concern since HMIC found that such assessments can be of poor quality and there is wide variety in the threshold for referral to health care professionals (HMIC, 2015). 
Moreover, not only are police officers supplied with limited statutory guidance regarding the questioning of child suspects, there is no stand-alone training for interviewing child suspects and the available training fails to give specific attention to such issues. While basic PIP 1 (formerly Tier 1 - see National Investigative Interviewing Strategy 2009) investigative interview training is mandatory for all police officers, such training does not engage with the specifics of child suspect interviews. Therefore, many police officers interviewing children regarding offences that do not require CID involvement will have no specialist training. Officers do not receive training on how to 'assess the capability of a suspect in terms of mental capacity, emotional wellbeing, general health and any other issues that would require the suspect to have additional support' (Hampshire Constabulary response) unless they complete the Serious and Complex Interview course (PIP 2). This is generally for detectives and not frontline officers. This training is aimed at CID officers and does not incorporate 'stand alone' sessions on child suspects. Although it is 'golden threaded' throughout the training, with issues such as the vulnerabilities of child suspects and the role of the appropriate adult (Derbyshire Constabulary response). PIP 3 courses focus specifically vulnerable witness and vulnerable suspect interviews.

Crucially, there is no guarantee that an officer with PIP 2 or PIP 3 training would interview a child suspect. Rather, the very clear message from almost all forces regarding the allocation of officers to interview was: the more serious the crime, the more highly trained the officer. Several forces were adamant that interviews for minor and volume crime, e.g. theft or shoplifting, could and would be conducted by a PIP 1 interviewer. Several were clear that this was appropriate: 'All police officers trained to basic level would be able to interview a child suspect' (Cumbria Constabulary response). Another force said: 'any officer could interview a child suspect' (Surrey Constabulary response; and, similar responses were received from Greater Manchester Police). There are several important consequences of this. First, it is very likely that police officers will revert to standard practices and techniques rather than tailoring their response to children (HMIC, 2015: 32). Secondly, logically, it could lead to situations where a child with a learning disability arrested for shoplifting is interviewed by an officer with basic training and a child with a normal level of IQ arrested for assault is interviewed by an officer with more advanced training. This is of great concern because theft is estimated to be by far the most common offence committed by children (Bateman, 2015). Furthermore, these types of minor offences are often dealt with by way of a diversion (a youth caution or youth conditional caution) based on an admission by the child. The imposition of a youth caution is by no means an administrative process, rather, it requires and recognises guilt and, although it is 'immediately spent' for the purposes of criminal record disclosure, it may still have important repercussions regarding employment, educational and travel opportunities. These cases will very rarely reach court, where the conduct of the interview may be scrutinised. It is in court that there lies the possibility of challenging the police interview, although on narrow grounds and arguably outdated case law. This would also seem more problematic given the increasing number of civilian investigators recruited to 'support police investigations', including investigations involving child suspects (Burgess, 2018). Civilian investigators receive less training that police officers but yet may be involved in the interviewing of children (Burgess, 2018). In the wake of the austerity, the number of civilian investigators is likely to increase, suggesting that the lack of a child focused approach will become a more pressing issue. 


\section{The Questioning of Children Compared}

The absence of specific guidance when interviewing child suspects is not in keeping with reforms to the interviewing of child witnesses, victims and complaints. We shall now compare these. First, the ABE guidance provides an extensive list of factors that should be considered for all child witnesses to explore in an assessment prior to interview. These include concepts that a learning-disabled child would often struggle with, such as time. For defendants, a Ground Rules Hearing would almost certainly be convened as appropriate questioning would be required (Criminal Procedure Rules 2015, 3.9(7)(b)). The questioning advocate would be expected to use the Advocacy Training Council's toolkit 4 for preparing to question a witness with a learning disability. For a suspect, there is no guarantee the child's needs would be identified, and considering $D P P \vee R$, it is likely that the child's disability may not be spotted by a police officer who is not trained to identify it. There is no guidance in PACE for a PIP 1 officer to prepare to interview a learning-disabled child.

Second, the Appendix E of the ABE guidance provides separate guidelines for interviewing a learning-disabled child witness. Simple examples are: they may need a longer rapport phase, an interview room organised to minimise sources of distraction and avoiding difficult concepts of time. In questioning witnesses, the judge controls questioning and is required to stop repetitive questioning $(R v$ Jones [2015] EWCA Crim 562). In contrast suspects can be questioned by a PIP 1 trained officer or member of police staff, who receive even less training. Quite simply, there is no equivalent guidance in Code of Practice $\mathrm{C}$, which in many forces the interviewer is directed to rely on exclusively. If it were a volume crime offence, it would very often not reach court and so the child could not use exclusionary rules of evidence in PACE (see below).

More generally, the ABE guidance remains the most extensive (over 200 pages) and most relevant given what is known about the problems with children. For example, it provides advice on dealing with acquiescence (e.g. paras $3.13,3.29$ ) and compliance (para 3.29), as well as detailed advice on avoiding abstract words, double negatives and jargon, checking understanding without simply asking 'do you understand?', difficulty with everyday concepts such as length and frequency of events, and, weight, height and age estimates. For advocates in court, training for questioning witnesses in serious sexual offence cases is now mandatory for all advocates (Bar Council 2016), and failure to complete such training is a disciplinary matter ( $R v$ Grant-Murray [2017] EWCA Crim 1228). Moreover, advances in 'special measures' are now being adopted in the family justice system (Munby, 2014). Consequently, it is inescapable that the policy and practice for interviewing child suspects has fallen behind advances in questioning vulnerable persons, especially that for witnesses. This woeful neglect is by no means corrected by the retrospective remedies permitted within PACE itself.

\section{Too Little, Too Late? Seeking Retrospective Remedies}

Although PACE offers little guidance regarding the questioning of child suspects, sections 76,78 and 83(2) can be used to exclude evidence obtained through oppression, in circumstances that would make it unreliable or, where its admission would have such as adverse effect on the fairness of the proceedings it should not be admitted. Section 76 applies to confessions and section 78 applies to any evidence that may render the proceedings unfair. As such it could be argued that they can act as a deterrent to police officers questioning a child in ways in which these safeguards might be triggered, if a child were to face trial. In reality, they provide limited means of redress. 
The first problem is that definitions used are derived from case law and do not reflect child specific concerns such as compliance, suggestibility or communication difficulties caused by lack of vocabulary or a learning disability. For example, section 76(2)(a) and (b) defines oppressive conduct as: 'an exercise of authority or power in a burdensome, harsh, or wrongful manner; unjust or cruel treatment of subjects, inferiors, etc., or the imposition of unreasonable or unjust burdens' ( $R v$ Fulling [1987] QB 426). Oppression does include questioning that is manipulative: 'by its nature, duration or other circumstances (including the fact of custody) excites hopes (such as the hope of release) or fears' induces the suspect to speak when otherwise he would have stayed silent' and a confession that is involuntary ( $R v$ Mushtaq [2005] 2 Cr App $\mathrm{R} 32$ ). These rules are used to examine the admissibility of police interviews of children but do not prevent inappropriate questioning going before a jury. In $R v$ Stringer [2008] EWCA Crim 1222, the defendant, aged 14 had a low/average IQ and had difficulties concentrating (this was the only information provided). He was asked a series of leading and complex questions in interview on the concept of virtual certainty of serious harm. The Court of Appeal held that the questioning 'was repetitive and in places was clumsy, but it was not suggested that it reached the stage of being oppressive or unfair' (para 32). The Court held that he had understood the questions and 'was not just going along with what was being put to him'. These inferences were made in the absence of expert evidence or similar assessment of the child's competence at the time of the interview. The reason for this is in the adversarial system: as the Court of Appeal said any such assessment is 'in the hands of the defence [lawyers]' (para 32). If any assessment had commissioned by the defence, it will not be disclosed if it is unhelpful for the defence's case. The only other avenue of defence is for a child to give evidence themselves about the process they may not have fully understood (whilst ironically having the benefit of safeguards around questioning in court which were lacking in the police station).

As regards section 78, there is no definition of what is unfair. It has been said that 'proceedings may become unfair if, for example, one side is allowed to adduce relevant evidence which, for one reason or another, the other side cannot properly challenge or meet' ( $R v$ Quinn, [1990] Crim LR 581). Normally, the court should consider first the circumstances in which the evidence was obtained and then whether it has an adverse effect on the proceedings. In assessing fairness, the judge should strike a balance between what is fair to both sides ( $R v$ Hughes [1988] Crim LR 519). A breach of the Codes of Practice may lead to exclusion but, as argued above, the available guidance on interviewing children is brief and key terms are undefined. It requires significant and substantial breaches of the Codes to trigger exclusion of the evidence and oppression and unreliability not confined to breaches of the Codes $(R v$ Walker [1998] Crim LR 211).

These short statutory provisions, therefore, are explained on an ad hoc basis without sufficient thought to what is known about the challenges of questioning children. They do not act as an effective deterrent or guide to the police when interviewing a child and act only as a retrospective remedy after a child has entered court proceedings. Furthermore, the operation of safeguards under sections 76, 78 and 83(2) of PACE only occurs after a child is charged and comes before a court. Additionally, these safeguards will not be available to children that are cautioned and diverted away from proceedings. This is significant because cautions are the primary out of court disposal imposed by police in custody (Evans 1994; Kemp 2014). Also 
there are no effective guarantees that an improperly conducted interview will not be used as a basis for conviction, especially if the trial and appeal courts are not in full possession of the facts concerning the child's competency in the interview. What is lacking is guidance, training and accepted practice to prevent not only unreliable evidence arising but also minimising harm to the child. This is exactly what the ABE Guidance and reforms to questioning in court attempt to achieve.

\section{Right to a fair trial}

The lack of a policy for appropriate questioning of a child suspect might engage a child's right to a fair trial (Article 6). The ECtHR has held it is 'essential that a child charged with an offence is dealt with in a manner which takes full account of his age, level of maturity and intellectual and emotional capacities, and that steps are taken to promote his ability to understand and participate in the proceedings' in order for a child to be able to participate effectively in a trial, a right guaranteed by Article 6 when read as a whole ( $V v U K$; $T v U K(2000) 30$ E.H.R.R. 121, paras 83-86). These principles can be found in the Criminal Practice Directions (3D.2, stemming from the adoption of key parts of the judgment of $V$ and $T v U K$ in an earlier Practice Direction in 2000). Effective participation requires:

'that the accused has a broad understanding of the nature of the trial process and of what is at stake for him or her, including the significance of any penalty which may be imposed. It means that he or she, if necessary with the assistance of, for example, an interpreter, lawyer, social worker or friend, should be able to understand the general thrust of what is said in court'. (SC v UK (2005) 40 E.H.R.R. 10, para 29).

A child's ability to effectively participate is not the same as their fitness to stand trial. In $S C v U K$, the defendant was fit to be tried but unable to participate unless tried in a specialist tribunal.

The ECtHR has extended this principle to the pre-trial stages, especially police questioning: "The right of an accused minor to effective participation in his or her criminal trial requires that he be dealt with with due regard to his vulnerability and capacities from the first stages of his involvement in a criminal investigation and, in particular, during any questioning by the police' (Panovits v Cyprus, para 67). This principle has yet to be applied in UK law. The House of Lords has stressed that the 'primary focus' of Article 6 is on the trial itself $(R(R) v$ Durham Constabulary [2005] 1 WLR 1184, para 12) and that in terms of assessing delay Article 6(1) is engaged at the earliest time at which a person is alerted to criminal proceedings - namely at the point of charge, not arrest or interview (Attorney General's Reference (No 2 of 2001) [2003] UKHL 68). Attorney General's Reference (no 2 of 2001) was not a case concerning children or police custody and the decision has subsequently been criticised by lower courts dealing with such cases and Panovits preferred (see HC at para 93). However, the Supreme Court has yet to deal with the question and so Panovits remains a case that a UK judge must take into account but is not bound by (Human Rights Act 1998, section 2). There are, however, strong reasons for holding that Panovits should apply and that the basis for it exists already.

First, the definition of effective participation above is very similar to the test in Annex G in Code of Practice C. In fact, Law Commission has recommended replacing 
the current fitness to stand trial test with a test of effective participation that incorporates decision-making capacity (2016: paras 3.32-3.35). It found that there were significant problems with young defendants whose abilities to effectively participate were significantly compromised by age, level of development, below average IQ and experience of trauma or abuse (paras 7.35-7.38, 2016). Surprisingly, we found no reference to use or application of Annex G in our data. Inclusion in the Code may not be sufficient: we have already explained the problems around assessment and that it requires significant and substantial breaches of the codes of practice to trigger exclusion of evidence. Article 6 is not guidance but a statutory duty imposed by section 6 of the Human Rights Act 1998. Errors can occur in interviewing that can lead to miscarriages of justice if such evidence is used to convict. The PACE safeguards do not always function effectively at the trial stage (e.g. $D P P \vee R$ ) or arguably on appeal if an assessment of a child is lacking (e.g. $R v$ Stringer). Whilst breaches of Article 6 must be considered in the context of the whole proceedings, an irremediable breach can occur at the pre-trial stage (Salduz v Turkey (2009) 49 EHRR 19; followed in Cadder v HM Advocate [2010] UKSC 43). Furthermore, respect for a child's dignity under article 40(1) of the United Nations Convention on the Rights of the Child (UNCRC, 2007), which informs the interpretation of the ECHR, requires that all professionals working in juvenile justice should have knowledge of child development and what is appropriate for their well-being.

Therefore, although Panovits is waiting in wings, it can and should be called upon to light the way forward in terms of avoiding miscarriages of justice through better assessment of child interviewees and allocation of appropriately trained interviewers. As is accepted with vulnerable witnesses, the questioner 'must adapt to the witness not the other way round' (R. v Lubemba [2014] EWCA Crim 2014). The challenge for the police is to make good on their policy for policing young people 'To improve the quality of policing for children and young people by acknowledging their differences, recognising their vulnerabilities and meeting their needs' (National Police Chief's Council, 2015), whilst investigating potential offending.

\section{Conclusion}

It is recognised by some of those who developed investigative interviewing (O'Mahony et al 2012) and very experienced senior criminal judges (Lord Judge 2013) that improvements in questioning children in the criminal justice system have moved extremely slowly and the processes that protect witnesses should be made available to suspects and defendants. For example, section 28 of the YJCEA 1999 was enacted allowing for pre-recorded cross-examination of vulnerable witnesses almost 20 years after the Pigott Report first recommended it. However, child suspects have come last and are almost entirely overlooked in these reforms. Whilst not an in-depth study, our data shows conclusively that there are no policies, guidance or standard operating procedures in place for interviewing child suspects, but an ad hoc and piecemeal approach. Our key finding is that the expertise of the interviewer depends on the seriousness of the crime not the abilities or vulnerabilities of the child. This is based on the mistaken and seemingly widespread belief that officers who receive basic training are sufficiently well equipped to interview any child suspect.

Given what is now known about child development and the profile of child suspects, the lack of specialist interviewing techniques will greatly hinder children's ability to give reliable evidence. The consequences of this are deeply worrying. 
Convictions or cautions might be based on false confessions or partly supported by corroborative remarks made in interview that are in fact a result of unrecognised forms of acquiescence, compliance or suggestibility. The children at greatest risk are those aged 14 and below who are interviewed for less serious offences. Without an appropriate expert assessment of a child or a sufficiently trained interviewer, the current safeguards in PACE are ineffective. An appeal to human rights law, and indeed the UNCRC, as part of child-friendly justice (Goldson and Muncie, 2012) can provide a legal justification for better assessment and training. We acknowledge that these improvements are not silver bullets, are costly and there remain practical obstacles in difficult cases, such as when an interview is urgently required and an appropriate assessor cannot be found. These should form part of a research agenda going forward so that the criminal justice system continues to adapt to the needs of vulnerable persons. We must have clear and effective communication at the start of the process in order to achieve a verdict that is true to the evidence and that does not risk injustice.

\section{End Notes}

1. These forces included Cumbria Constabulary, Cleveland Police, Durham Constabulary, Essex Police and West Yorkshire Police.

2. Personal communication from several police officers following a presentation of this research at the Children, Justice and Communication Conference held at the University of Portsmouth (4-5 May 2017).

\section{References}

All Party Parliamentary Group for Children (2013-2014) "It's all about trust": Building good relationships between children and the police. Report of the inquiry held by the All Party Parliamentary Group for Children 2013-2014. Available Online: https://www.basw.co.uk/system/files/resources/basw_20117-10_0.pdf

Bar Council (2016) Bar Council launches vulnerable witness training. Available Online: $\quad$ http://www.barcouncil.org.uk/media-centre/news-and-pressreleases/2016/november/bar-council-launches-vulnerable-witness-advocacytraining/

Bateman, T. (2017) The State of Youth Justice 2017: An Overview of Trends and Developments. Available Online: http://thenayj.org.uk/wpcontent/uploads/2017/09/State-of-Youth-Justice-report-for-web-Sep17.pdf.

Bowcott, O. (2015) Strip-searched girl's family sues Merseyside Police. The Guardian, 22 January

Bryan, K., Freer, J. and Furlong, C. (2007) Language and Communication Difficulties in Juvenile Offenders. International Journal of Language and Communication Disorders 42: 505-520.

Baroness E Butler-Sloss (1988) Report of the Inquiry into child abuse in Cleveland in 1987. Cm 142 London: HMSO.

Blandón-Gitlin, I. and Pezdek, K. (2009) .Children's memory in forensic contexts. In: Bottoms, B., Najdowski, C. and Goodman, G. (Eds), Children as Victims, Witnesses and Offenders. New York, Guildford Press.

Bruck, M. and Ceci, S. (2004) Forensic developmental psychology: unveiling four common misconceptions. Current Directions in Psychological Science, 13(6): 229232.

Bull, R. (2014) Investigative Interviewing. New York, Springer. 
Charles, C. (2012) Special Measures for Vulnerable and Intimidated Witnesses: Research exploring the decisions and actions taken by prosecutors in a sample of CPS files. London: Crown Prosecution Service.

College of Policing (2013) Investigative interviewing. London: College of Policing. Available Online: https://www.app.college.police.uk/appcontent/investigations/investigative-interviewing/

Criminal Practice Directions [2015] EWCA Crim 1567

Dehaghani, R. (2017) "Vulnerable by law but not by nature": Examining Child and Youth Vulnerability in the Context of Police Custody. Journal of Social Welfare and Family Law, 39(4): 454-472.

Evans, R. (1994). Police interrogations and the Royal commission on criminal Justice. Policing and Society: An International Journal, 4:1, 73-81.

Feld, B. (2006) Police Interrogation of Juveniles: An Empirical Study of Policy and Practice. Journal of Criminal Law and Criminology, 97: 219-316.

Feld, B. (2014) Kids, Cops and Confessions: Inside the Interrogation Room. New York: New York University Press.

Gander, K. (2014) Metropolitan police strip-searched thousands of children in five years. The Independent, 17 March.

Gooch, K. (2013) Treating 17-year olds in Police Custody as Children, not Adults. Journal of Criminal Law 77(4): 281-285.

Goldson, B. and Munice, J. (2012) Towards a global 'child friendly' youth justice. International Journal of Law, Crime and Justice, 40: 47-64

Gregory, M. (2004). Fitness to be interviewed. Journal of Clinical Forensic Medicine, 11(5): $260-263$

Griffiths, L. and Milne, B. (2006) Will it end in tiers?: Police interviews with suspects in Britain. In: Williamson, T. (ed.), Investigative interviewing: rights, research, regulation. Cullompton: Willan, 167-189.

Grisso, T. (2004) Double Jeopardy: Adolescent Offenders with Mental Disorders. Chicago: University of Chicago Press.

Grisso, T., Steinberg, L., Woolard, J., Cauffman, E., Scott, E., Graham, S., Lexcen, F., Reppucci, N. and Schwartz, R. (2003) Juveniles competence to stand trial: a comparison of adolescents' and adults' capacities as trial defendants. Law and Human Behavior, 27(4): 333-63.

Gudjonsson, G. (1990) One hundred alleged false confession cases: some normative data. British Journal of Clinical Psychology, 29(2): 249-50.

Harrington, R. and Bailey, S. (2005) Mental Health Needs and Effectiveness of Provision for Young Offenders in Custody and in the Community. London: Youth Justice Board.

Her Majesty's Inspectorate of the Crown Prosecution Service and Her Majesty's Inspectorate of Constabulary (2014) Achieving Best Evidence in Child Sexual Abuse Cases - A Joint Inspection Report. London: Her Majesty's Inspectorate of the Crown Prosecution Service.

Her Majesty's Inspectorate of Constabulary (2015) The Welfare of Vulnerable People in Police Custody. London: Her Majesty's Inspectorate of Constabulary.

Her Majesty's Inspectorate of Constabulary and Her Majesty's Inspectorate of Constabulary of Fire and Rescue Services (2019) Report of an unannounced inspection visit to police custody suites in Metropolitan Police Service. London: Her Majesty's Inspectorate of Constabulary. 
Hughes, N., Williams, H., Chitsabesan, P., Davies, R. and Mounce, L. (2012) Nobody Made the Connection: The prevalence of neurodisability in young people who offend. London: Office of the Children's Commissioner.

Jivanda, T. (2014) Hundreds of mentally ill children locked in police cells, some for more than 24 hours. The Independent, 26 January.

Lamb, M, La Rooy, D, Malloy, L and Katz, C. (2011) Children's Testimony: A Handbook of Psychological Research and Forensic Practice. Chichester: Wiley.

Law Commission (2016) Unfitness to Plead. Volume 1: Report. Law Com No 364. London: HMSO.

Lord Judge (2013) The Evidence of Child Victims: the Next Stage. Bar Council Annual Law Reform Lecture. 21st November. Available Online: https://www.barcouncil.org.uk/media/241783/annual_law_reform_lecture_rt_hon_ the lord_judge_speech_2013.pdf.

Jacobson, J. and Talbot, J. (2009) Vulnerable Defendants in the Criminal Courts: a review of provision for adults and children. London: Prison Reform Trust.

Kemp, V. (2014) 'PACE, performance targets and legal protections', Criminal Law Review, 4, 278-297.

Kemp, V. and Hodgson, J. (2016) England and Wales: Empirical Findings. In: Panzavolta, M., de Vocht, D., van Oosterhout, M. and Vanderhallen, M. (ed) Interrogating Young Suspects: Procedural Safeguards from an Empirical Analysis. Cambridge: Intersentia, 127-181.

Kemp, V., Pleasence, P. and Balmer, N.J. (2011) Children Young People and Requests for Police Station Legal Advice: 25 years on from PACE. Youth Justice, 11(1): 2846.

McKinnon, I., Thorp, J., Grubin, D. (2015) Improving the detection of detainees with suspected intellectual disability in police custody. Advances in Mental Health and Intellectual Disabilities, 9(4): 174-185.

Ministry of Justice (2011) Achieving Best Evidence. London, Ministry of Justice

Ministry of Justice (2017) Youth Justice Statistics. London, Ministry of Justice

Munby P. (2014) View from the President's Chambers. 4th June 2014. Available Online: https://www.judiciary.uk/publications/view-from-presidents-chambers/.

Norfolk, G.A. (1996) Fitness to be interviewed and the appropriate adult scheme: a survey of police surgeons' attitudes. Journal of Clinical Forensic Medicine, 3(1): 913.

O’Mahony, B, Milne, B and Grant, T. (2012) To Challenge, or not to Challenge? Best Practice when Interviewing Vulnerable Suspects. Policing, 6(3): 301-313.

Panzavolta and de Vocht (2015) Introduction. In: Panzavolta, M., de Vocht, D., van Oosterhout, M. and Vanderhallen, M. (eds) Interrogating Young Suspects, Procedural Safeguards from a Legal Perspective, Cambridge: Intersentia.

Peel, M. (2017) Assessing an individual's fitness to be interviewed in police custody. Nursing Standard, 31(40), 32-50.

Pierpoint, H. (2000a) Taking the Protection of Vulnerable Suspects Seriously: Putting Appropriate Adults through their Paces. Practice, 12(3): 49-60.

Pierpoint, H. (2000b) How appropriate are volunteers as appropriate adults for young suspects? The appropriate adult system and human rights. Journal of Social Welfare and Family Law, 22(4): 383-400.

Pierpoint, H. (2006) Reconstructing the role of the appropriate adult in England and Wales. Criminology and Criminal Justice, 6(2): 219-237.

Pierpoint, H. (2011) Extenting and Professionalising the Role of the Appropriate Adult. Journal of Social Welfare and Family Law, 2011 33(2): 139-155. 
Pleasence, P, Kemp, V. and Balmer N.J. (2011) The justice lottery? Police station advice 25 years on from PACE', Criminal Law Review, 1: 3-18.

Protheroe, D and Roney, G. (1996). 'Assessing detainees' 'fitness to be interviewed' Psychiatric Bulletin 20, 104-105.

Quinn, K. and Jackson, J. (2007) Of Rights and Responsibilities: Police Interviewing with Young Suspects in Northern Ireland. British Journal of Criminology, 47(2): 234-255.

Redlich, A. and Goodman, G. (2003), 'Taking responsibility for an act not committed: the influence of age and suggestibility', Law and Human Behavior, 27(2): 141-56.

Sanders, A. and Young, R (2012) 'From Suspect to Trial' In: Maguire, M., Morgan, R. and Reiner, R. (eds) Oxford Handbook of Criminology. $5^{\text {th }}$ Edn. Oxford: Oxford University Press

Scott-Hayward, C.S. (2007) 'Explaining Juvenile False Confessions: Adolescent Development and Police Interrogation' Law and Psychology Review 31: 53-76

Skinns, L. (2011) The Overnight Detention of Children in Police Cells. London: Howard League for Penal Reform.

Soukara, S., Bull, R., Vrij, A., Turner, M. and Cherryman, J. (2009) 'What Happens in Police Interviews of Suspects: Tactics and Confessions,' Psychology, Crime and Law. 15(6): 493-506.

Talbot, J. (2010) Seen and Heard: Supporting vulnerable children in the youth justice system. London: Prison Reform Trust

Taylor, C (2016) Review of the Youth Justice System in England and Wales. London: Ministry of Justice.

United Nations Committee on the Rights of the Child (2007) General Comment on Children's Rights in Juvenile Justice. CRC/C/GC/10. Geneva: United Nations.

Vizard, E. (2006). Child Defendants. (Occasional Paper OP56). Royal College of Psychiatrists. Available from: http://www.rcpsych.ac.uk/usefulresources/publications/collegereports/op/op56.asp $\underline{x}$.

Walsh, D. and Bull, R. (2010) 'What really is effective in interviewing suspects? A study comparing interview skills and interview outcomes,' Legal and Criminological Psychology 15: 305-321.

Williamson, T. (2015) Investigative Interviewing: Rights, research, regulation. Cullompton: Willan. 